\title{
Antimicrobial activity of Spondias mombin $L$. aqueous and hydroethanolic extracts on Enterococcus faecalis and Pseudomonas aeruginosa - an in vitro study
}

Atividade antimicrobiana de extratos aquosos e hidroetanólicos de Spondias mombin L. sobre

Enterococcus faecalis e Pseudomonas aeruginosa - um estudo in vitro

Actividad antimicrobiana de los extractos acuosos e hidroetanólicos de Spondias mombin L. en

Enterococcus faecalis y Pseudomonas aeruginosa - un estudio in vitro

Received: 01/13/2021 | Reviewed: 01/17/2021 | Accept: 01/21/2021 | Published: 01/28/2021

Ingrid Priscila Américo de Lima

ORCID: https://orcid.org/0000-0003-0888-5993

Federal University of Rio Grande do Norte, Brazil

E-mail: ingrid-priscila@hotmail.com

Rivanaldo Adriano Holanda Alves

ORCID: https://orcid.org/0000-0001-8057-1230

Federal University of Rio Grande do Norte, Brazil

E-mail: dradrianoholanda@gmail.com

Juliana de Sousa Lima Mayer

ORCID: https://orcid.org/0000-0002-2263-1212

Federal University of Rio Grande do Norte, Brazil E-mail: juliufrn@gmail.com

Maria Regina Macêdo Costa

ORCID: https://orcid.org/0000-0002-6362-502X

Federal University of Rio Grande do Norte, Brazil

E-mail: mariareginamacedo@yahoo.com.br

Angélica Kercya Pereira de Mendonça

ORCID: https://orcid.org/0000-0002-9769-9633

Federal University of Rio Grande do Norte, Brazil

E-mail: angelica_kercya@hotmail.com

Emanuelle Louyde Ferreira de Lima

ORCID: https://orcid.org/0000-0003-2341-7565

Federal University of Rio Grande do Norte, Brazil

E-mail: emanuellelouyde@ @otmail.com

Silvana Maria Zucolotto Langassner

ORCID: https://orcid.org/0000-0002-2768-0793

Federal University of Rio Grande do Norte, Brazil

E-mail: szucolotto@hotmail.com

Fábio Roberto Dametto

ORCID: https://orcid.org/0000-0001-8108-8523

Federal University of Rio Grande do Norte, Brazil

E-mail: dametto71@ hotmail.com

Kenio Costa de Lima

ORCID: http://orcid.org/0000-0002-5668-4398

Federal University of Rio Grande do Norte, Brazil

E-mail: limke@uol.com.br

Ruthinéia Diógenes Alves Uchoa Lins

ORCID: https://orcid.org/0000-0002-0047-5976

Federal University of Rio Grande do Norte, Brazil

E-mail: aruthineia@gmail.com

\begin{abstract}
Objective: To chemically characterize Spondias mombin L. extracts and to evaluate the in vitro antimicrobial activity of these extracts on Enterococcus faecalis and Pseudomonas aeruginosa. Material and methods: Both extracts were submitted to phytochemical prospecting and thin layer chromatography (TLC) analysis prior to determination of Minimum Inhibitory Concentration (MIC), Minimum Inhibitory Adhesion Concentration (MIAC) and Bactericidal Kinetics (BK). The Student's t-test was used to compare MIC results at the 5\% significance level. The chemical characterization, MIAC and BK data were analyzed descriptively. Results: Phenolic compounds, flavonoids, tannins and saponins were detected in the extracts. The hydroethanolic extracts in different concentrations showed statistically superior inhibitory bacterial growth activity $(\mathrm{p}<0.05)$ compared to the control against the two investigated microorganisms, whereas the aqueous extracts (also in different concentrations) was statistically superior $(\mathrm{p}<0.05)$ to the control only against Pseudomonas
\end{abstract}


aeruginosa. The anti-adherent effect of both extracts was superior to that of the control for P. aeruginosa, and similar to that for E. faecalis. In their crude and diluted concentrations, aqueous and hydroethanolic extracts showed bactericidal action within the first two to four hours of contact with the bacteria. Conclusion: Spondias mombin L. extracts in different concentrations showed superior antimicrobial activity than $0.12 \%$ chlorhexidine digluconate against the microorganisms with this activity associated to the chemical characterization of these extracts.

Keywords: Phytotherapy; Anti-infective agents; Microbiology.

\section{Resumo}

Objetivo: Caracterizar quimicamente os extratos de Spondias mombin L. e avaliar a atividade antimicrobiana in vitro desses extratos sobre Enterococcus faecalis e Pseudomonas aeruginosa. Material e métodos: Ambos os extratos foram submetidos à prospecção fitoquímica e análise de cromatografia em camada delgada (CCD) antes da determinação da Concentração Inibitória Mínima (CIM), Concentração Inibitória Mínima de Adesão (MIAC) e Cinética Bactericida (BK). O teste $\mathrm{t}$ de Student foi usado para comparar os resultados do MIC ao nível de significância de 5\%. A caracterização química, os dados MIAC e BK foram analisados descritivamente. Resultados: compostos fenólicos, flavonóides, taninos e saponinas foram detectados nos extratos. Os extratos hidroetanólicos em diferentes concentrações apresentaram atividade inibitória de crescimento bacteriano estatisticamente superior $(\mathrm{p}<0,05)$ em comparação ao controle contra os dois microrganismos investigados, enquanto os extratos aquosos (também em diferentes concentrações) foram estatisticamente superiores $(\mathrm{p}<0,05)$ ao controle apenas contra Pseudomonas aeruginosa. O efeito anti-aderente de ambos os extratos foi superior ao do controle para $P$. aeruginosa e semelhante ao de E. faecalis. Em suas concentrações bruta e diluída, os extratos aquosos e hidroetanólicos apresentaram ação bactericida nas primeiras duas a quatro horas de contato com a bactéria. Conclusão: Extratos de Spondias mombin L. em diferentes concentrações apresentaram atividade antimicrobiana superior ao digluconato de clorexidina $0,12 \%$ contra os microrganismos com essa atividade associada à caracterização química desses extratos.

Palavras-chave: Fitoterapia; Agentes anti-infecciosos; Microbiologia.

\section{Resumen}

Objetivo: Caracterizar químicamente extractos de Spondias mombin L. y evaluar la actividad antimicrobiana in vitro de estos extractos sobre Enterococcus faecalis y Pseudomonas aeruginosa. Material y métodos: Ambos extractos fueron sometidos a prospección fitoquímica y análisis de cromatografía en capa fina (TLC) antes de la determinación de la Concentración Mínima Inhibitoria (MIC), la Concentración Mínima de Adhesión Inhibidora (MIAC) y la Cinética Bactericida (BK). Se utilizó la prueba t de Student para comparar los resultados de la CIM al nivel de significancia del $5 \%$. Los datos de caracterización química, MIAC y BK se analizaron de forma descriptiva. Resultados: En los extractos se detectaron compuestos fenólicos, flavonoides, taninos y saponinas. Los extractos hidroetanólicos en diferentes concentraciones mostraron una actividad inhibidora del crecimiento bacteriano estadísticamente superior ( $p<0.05)$ en comparación con el control contra los dos microorganismos investigados, mientras que los extractos acuosos (también en diferentes concentraciones) fueron estadísticamente superiores $(\mathrm{p}<0.05)$ al control solamente. contra Pseudomonas aeruginosa. El efecto anti-adherente de ambos extractos fue superior al del control de P. aeruginosa y similar al de E. faecalis. En sus concentraciones brutas y diluidas, los extractos acuosos e hidroetanólicos mostraron acción bactericida dentro de las primeras dos a cuatro horas de contacto con la bacteria. Conclusión: Los extractos de Spondias mombin L. en diferentes concentraciones mostraron una actividad antimicrobiana superior al digluconato de clorhexidina al $0,12 \%$ contra los microorganismos con esta actividad asociada a la caracterización química de estos extractos.

Palabras clave: Fitoterapia; Agentes antiinfecciosos; Microbiología.

\section{Introduction}

Facing the limitations of mechanical oral hygiene methods, antimicrobial agents have been proposed with the purpose of reducing the adhesion, growth and proliferation of microorganisms in the oral environment and also to modify the biochemical activity and ecology of dental biofilm. Several substances, including enzymes, essential oils, and bisbiguanides, among others, have been used as inhibitors to dental biofilm formation and accumulation, as well as in the control of different oral infections often caused by superinfecting microorganisms such as Enterococcus faecalis and Pseudomonas aeruginosa. Superinfection is generally defined as a second infection superimposed on an earlier infection, with the superinfecting pathogen generally resistant to the agent used to treat the initial infection.

Enterococcus faecalis is a gram-positive coccus inhabiting the gastrointestinal tract, which is often associated with infections involving the urinary tract, cardiovascular system and surgical wounds (O'Driscoll \& Crank, 2015). Once present in the buccal environment, which is relatively common, it has the capacity to form biofilms and penetrate the dentinal tubules, participating in the pathogenesis of oral diseases such as caries, periodontal disease and endodontic infections (Chakraborty \& 
Brantner, 1999; Rams et al., 2013; Wei \& Jingping, 2015). This microorganism is often isolated from root canals (Zoletti et al., 2011), is highly related to failures in endodontic therapy (Lysakowska et al., 2016) and can still be found in high proportions in the subgingival biofilm of individuals with periodontitis (Colombo et al., 2013). In addition, it can spread through the bloodstream, reaching vital organs, developing systemic diseases or causing sepsis in immunocompromised individuals (Beganovic et al, 2013).

Pseudomonas aeruginosa is a gram-negative bacillus present in dispersed form in the environment, but which can be found in human microbiota in immunosuppressive scenarios of the individual, and is strongly associated with nosocomial infections (Peña, et al., 2013; Lucena et al., 2014). It also has the ability to organize into biofilm and produce toxins and extracellular enzymes. In the oral environment, this microorganism can be found inside deep periodontal pockets (Souto et al., 2014), and is associated with bacteremia (Peña, et al., 2013). In addition, it colonizes dental prostheses, and its occurrence is strongly associated with an increased risk of aspiration pneumonia (O'donnell et al., 2016). The precariousness of basic sanitation and the lack of care of oral hygiene by inpatients or patients with low physical autonomy can increase the contamination risk by Pseudomonas aeruginosa (O'donnell et al., 2016) and raise the level of this microorganism in the saliva, facilitating its aspiration to the lungs (Caldas et al., 2015).

Another important factor related to the Enterococcus faecalis and Pseudomonas aeruginosa microorganisms is their resistance to several conventional synthetic antimicrobial agents, including antibiotics (Colombo et al., 2013), which makes it difficult to eradicate them. For this reason, the need to seek new treatment strategies that eliminate these microorganisms has become increasingly evident. The increased resistance of these and other bacterial strains to conventional synthetic antimicrobial agents, the high cost of these substances and their limitations in long-term use due to their potential adverse effects have stimulated a search for natural products that are easily accessible to the population with little or no side effects, which enable controlling dental biofilm (Allaker \& Douglas, 2009) and can eliminate superinfecting microorganisms present in the buccal environment.

In this sense, herbal medicines have emerged as a viable and extremely relevant alternative. Several studies have shown that multiple plant extracts exhibit antimicrobial activity without exerting cytotoxicity, depending on concentration (Cabral et al., 2016; Kadan et al., 2016). Among them, we highlight Spondias mombin L. (S. mombin L.) leaf extract, popularly known in Brazil as Cajá (Abo et al., 1999). This species is widely found in countries such as Brazil, Peru, Venezuela, Bolivia, Colombia, Guyana, French Guiana, Suriname, Costa Rica, Belize, as well as in southern Mexico and the Antilles (Adedokun et al., 2010). In vitro experiments have revealed that S. mombin L. leaf extract presents anti-inflammatory and anti-oxidant actions, in addition to antimicrobial activity (Cabral et al., 2016; Gomes et al., 2020; Nworu et al., 2011).

In view of the abovementioned information, the objective of this study was to chemically characterize the aqueous and hydroethanolic extracts of S. mombin L. leaves and to evaluate the in vitro antimicrobial activity of these extracts on Enterococcus faecalis and Pseudomonas aeruginosa superinfecting microorganisms compared to the antimicrobial activity of $0.12 \%$ chlorhexidine digluconate solution (control). The null hypothesis was that there would be no difference between the antimicrobial activity of $S$. mombin $L$. extracts and the antimicrobial activity of $0.12 \%$ chlorhexidine digluconate on Enterococcus faecalis and Pseudomonas aeruginosa microorganisms.

\section{Methodology}

\subsection{Plant material}

The raw plant material was collected in Natal/RN, Rio Grande do Norte, Brazil, under natural conditions and without any addition of chemical compounds by chemical fertilizers, pesticides or insecticides. The voucher specimen was deposited in 
the herbarium of the Federal University of Rio Grande do Norte (UFRN), with exsicata number 12252. The S. mombin L. leaves were dried in the shade at room temperature for two weeks. After drying, the leaves were crushed in a knife mill.

\subsection{Preparation of Spondias mombin L. extracts}

A maceration extract was prepared from $450 \mathrm{~g}$ of $S$. mombin $L$. plant extract, which consisted of leaving the extract in contact with ethanol $(\mathrm{C} 2 \mathrm{H} 6 \mathrm{O}, 70: 30, \mathrm{v} / \mathrm{v})$ for seven days. The extract was filtered after this period, obtaining the hydroethanolic extract of the leaves (HE). Aqueous extract (AE) was obtained by the decoction method, which consisted of leaving the extract in contact with boiling water for 15 minutes. The aqueous and hydroethanolic extracts obtained were concentrated under reduced pressure using a rotary evaporator at $45^{\circ} \mathrm{C}$. Both extracts were then lyophilized.

\subsection{Phytochemical prospecting of Spondias mombin L. extracts}

A preliminary phytochemical screening of the S. mombin $L$. aqueous and hydroethanolic extracts was initially performed, in which the main characterization reactions for secondary metabolites were tested. The studied metabolites were: polyphenols, flavonoids, tannins, saponins and alkaloids. An amount of the ferric chloride oxidizing agent $\left(\mathrm{FeCl}_{3}\right)$ was added to the crude extracts to identify the phenols, with the reaction considered positive through the development of a bluish-green coloration. The Shinoda test (concentrated $\mathrm{HCl}$ and magnesium powder) was used to identify flavonoids, with the reaction considered positive by the development of a variable orange to green color. The tannins were characterized by the precipitation reaction with gelatin, and the reaction was considered positive with the development of a precipitate. In addition, the foam test was used in order to detect the presence of saponins, and the reaction was considered positive by persistence of foam for 15 minutes. Finally, the alkaloid test was based on formation reactions of insoluble complexes produced by specific reagents such as: Dragendorff (yellow/orange precipitate formation), Mayer (white precipitate formation), Wagner (dark brown precipitate formation) and Bertrand (formation of yellowish white precipitate).

\subsection{Analysis of Spondias mombin L. extracts by Thin Layer Chromatography (TLC)}

The $S$. mombin $L$. hydroethanolic and aqueous extracts were analyzed by TLC using two solvent systems for elution (ethyl acetate:formic acid:water 8.4:0.7:0.7 v/v/v/v; toluene:ethyl acetate:formic acid 5:5:0.5 v/v/v). Natural Reagent A, which is specific for flavonoids, may be used as a developer and may also disclose other phenolic compounds.

\subsection{Culture of microorganisms}

Enterococcus faecalis ATCC 29212 and Pseudomonas aeruginosa ATCC 9027 bacterial strains were used in this study. These samples were obtained in BHI (Brain Heart Infusion - DIFCO®, Michigan, USA) and spiked on Petri dishes containing Blood Agar (Columbia Blood Agar Base - DIFCO ${ }^{\circledR}$, Michigan, USA) with a disposable handle in three directions: horizontal, vertical and diagonal, remaining in the stove at $37^{\circ} \mathrm{C}$ for 24 hours. Bacterial colonies were subsequently removed from this plate, seeded in BHI (Brain Heart Infusion - DIFCO ${ }^{\circledR}$ Michigan, USA) and incubated at $37^{\circ} \mathrm{C}$ for 18 to 20 hours, then finally underwent the following evaluation tests of the extracts' antimicrobial activity: Minimum Inhibitory Concentration (MIC), Minimum Inhibitory Adhesion Concentration (MIAC) and Bactericidal Kinetics (BK).

\subsection{Determination of Minimum Inhibitory Concentration (MIC)}

This research is an experimental study, in vitro, which used the methodology adapted from Bauer et al. (1966) to determine the MIC (Bauer et al., 1966; Pereira et al., 2018). The BHI (BHI-Brain Heart Infusion - DIFCO®, Michigan, USA) was inoculated with each bacterial growth in five petri dishes containing Mueller Hinton Agar (DIFCO®, Michigan, USA), 
and five equidistant, standardized holes were created with six mm diameter (on each plate) (Bauer et al., 1966). Sixty $\mu 1$ of the test substance (HE and $\mathrm{AE}$ until dilution of 1:512 in distilled water) were introduced into the orifices and the plates were incubated at $37^{\circ} \mathrm{C}$ for 48 hours. Each assay was performed in triplicate on each lineage. The same procedure was used for positive control with $0.12 \%$ chlorhexidine digluconate (Periogard®, Colgate-Palmolive Company, New York, USA). The MIC was the lowest extract concentration capable of inhibiting microbial growth, represented by the presence of an inhibition halo measured in mm with the aid of a pachymeter (Eccofer®, China). Only inhibition halos with diameters equal to or greater than $8 \mathrm{~mm}$ were considered valid for determining bacterial growth inhibitory activity, according to the methodology of Smânia et al. (1999) (Smania Jr et al., 1999).

\subsection{Determination of Minimal Inhibitory Adherence Concentration (MIAC)}

The Minimum Inhibitory Adhesion Concentration (MIAC) of S. mombin L. extracts was determined using concentrations corresponding to the crude extract up to a 1:512 dilution. From bacterial growth, the Enterococcus faecalis and Pseudomonas aeruginosa bacteria were subcultured at $37^{\circ} \mathrm{C}$ in Mueller-Hinton broth (DIFCO, Michigan, USA). Then, $0.9 \mathrm{ml}$ of the subculture was distributed into hemolysis tubes and $0.1 \mathrm{ml}$ of the solution corresponding to the extract dilutions was added. Incubation occurred at $37^{\circ} \mathrm{C}$ for 24 hours in microaerophylia, with the tubes tilted at $30^{\circ}$. The reading was done through visually observing the bacterial adherence to the tube walls after shaking it. Each assay was performed in duplicate against each selected lineage. The same procedure was performed for positive control with $0.12 \%$ chlorhexidine digluconate (Periogard $\AA$, Colgate-Palmolive Company, New York, USA). The lowest extract concentration capable of preventing microorganism adhesion to the glass tube was considered the MIAC.

\subsection{Determination of Bactericidal Kinetics (BK)}

The bactericidal activity of S. mombin L. extracts was evaluated by the method of Peyret et al. (1990) (Peyret et al., 1990). Enterococcus faecalis and Pseudomonas aeruginosa samples were inoculated in nutrient broth (BHI-DIFCO, Michigan, USA), incubated at $37^{\circ} \mathrm{C}$ for 18 to 20 hours and subcultured in Mueller Hinton Broth (DIFCO, Michigan, USA) for 1 one hour, resulting in an inoculum of $106 \mathrm{CFU} / \mathrm{mL}$. Next, $1 \mathrm{~mL}$ of extracts (crude and MIC) were added to $9 \mathrm{~mL}$ of bacterial culture, and $1 \mathrm{~mL}$ of $0.12 \%$ chlorhexidine digluconate was added to the control tube. The tubes were maintained in the oven at $37^{\circ} \mathrm{C}$ for 24 hours, and aliquots were removed after 2 (two), 4 (four), 6 (six) and 24 hours of incubation and plated on Mueller Hinton Agar plates (DIFCO, Michigan, U.S). Each assay was performed in duplicate against each selected lineage. The plaques were read after incubation for 24 hours at $37^{\circ} \mathrm{C}$ by the colony-forming unit standard counting method (CFU), observing the bactericidal potential of the extracts and $0.12 \%$ chlorhexidine digluconate in the determined time intervals.

\subsection{Statistical analysis}

The results concerning the Minimum Inhibitory Concentration (MIC) were collected, organized and presented in tables, with the respective halo averages indicating bacterial growth inhibition. These values were subsequently transferred to a database and the statistical parameters that included the values of the respective means and standard deviations were calculated. A 95\% confidence level was used to obtain the intervals. The Student's t-test was used at the 5\% level of significance to compare the inhibition halos obtained from the Minimum Inhibitory Concentrations (MIC) of the extracts with each other and in relation to the $0.12 \%$ chlorhexidine digluconate against the two investigated microorganisms. The chemical characterization data of the extract, Minimum Inhibitory Adherence Concentration (MIAC) and Bactericidal Kinetics (BK) were organized and analyzed descriptively. 


\section{Results}

\subsection{Phytochemical prospecting}

The following plant secondary metabolites were detected by phytochemical prospecting the S. mombin L. extracts: phenolic compounds, flavonoids, tannins and saponins. The characterization reaction was only negative for the presence of alkaloids, since no precipitate formation or color change occurred.

\subsection{Thin-layer Chromatography (TLC) analysis}

Four bands with yellow staining were observed in the TLC analysis after Natural Reagent A development, which is a specific flavonoid developer, thus characterizing the presence of flavonoids in the aqueous (AE) and hydroethanolic (HE) extracts of S. mombin L., in addition to a blue color band suggestive of phenolic acid also being verified (Figure 1).

Figure 1. TLC analysis of the AE and HE, showing the presence of flavonoids and phenolic acids in both extracts. (Developer: Natural Reagent A/UV $365 \mathrm{~nm}$ ). Mobile phase: toluene (ethyl acetate:formic acid 5:5:0.5).

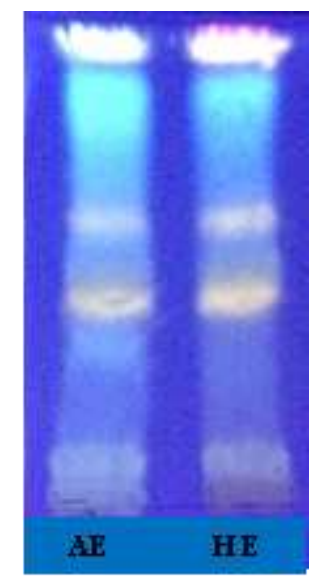

Source: Authors.

Figure 1 shows that the flavonoids were located in both extracts, being represented by the yellow color, while the blue color suggests the presence of phenolic acids.

\subsection{Minimal Inhibitory Concentration (MIC) analysis}

The two S. mombin L. extracts (AE and HE) showed activity against the tested microorganisms, with inhibition halos varying from 10 to $31 \mathrm{~mm}$, with their means described in Table 1. AE exhibited bacterial growth inhibitory activity until 1:128 $(3.90 \mathrm{mg} / \mathrm{ml})$ dilution for Enterococcus faecalis, and up to $1: 256(1.95 \mathrm{mg} / \mathrm{ml})$ dilution for Pseudomonas aeruginosa, whereas HE exhibited the same activity up to $1: 256(1.95 \mathrm{mg} / \mathrm{ml})$ dilution for Enterococcus faecalis, and up to $1: 512(0.97 \mathrm{mg} / \mathrm{ml})$ dilution for Pseudomonas aeruginosa. However, in comparing these bacterial growth inhibitory activities between the two investigated extracts, it was observed that the S. mombim L. HE was statistically superior to the AE (p <0.038) only at the concentration $31.25 \mathrm{mg} / \mathrm{ml}$ (1:16 dilution) for the Enterococcus faecalis bacterium (Table 1). 
Table 1. Statistical results obtained from the comparison between the inhibition halo means of the S. mombin L. aqueous and hydroethanolic extracts in different concentrations against the Enterococcus faecalis and Pseudomonas aeruginosa microorganisms.

\begin{tabular}{|c|c|c|c|c|c|c|c|c|c|}
\hline & & \multicolumn{4}{|c|}{$\begin{array}{l}\text { Enterococcus faecalis } \\
\text { ATCC } 29212\end{array}$} & \multicolumn{4}{|c|}{$\begin{array}{c}\text { Pseudomonas aeruginosa } \\
\text { ATCC } 9027\end{array}$} \\
\hline & & Mean & & SD & $p$ & Mean & & SD & $p$ \\
\hline \multirow{2}{*}{$\begin{array}{c}1: 1 \\
500 \mathrm{mg} / \mathrm{mL}\end{array}$} & Aqueous & 27,00 & \pm & 4,359 & \multirow{2}{*}{0,276} & 27,00 & \pm & 1,732 & \multirow{2}{*}{0,613} \\
\hline & Hydroethanolic & 30,67 & \pm & 2,517 & & 28,00 & \pm & 2,646 & \\
\hline & Aqueous & 20,33 & \pm & 6,028 & \multirow{2}{*}{0,191} & 21,67 & \pm & 2,082 & \multirow{2}{*}{0,152} \\
\hline $250 \mathrm{mg} / \mathrm{mL}$ & Hydroethanolic & 26,67 & \pm & 3,512 & & 18,67 & \pm & 2,082 & \\
\hline $1: 4$ & Aqueous & 19,00 & \pm & 4,583 & \multirow{2}{*}{0,330} & 19,33 & \pm & 2,517 & \multirow{2}{*}{0,441} \\
\hline $125 \mathrm{mg} / \mathrm{mL}$ & Hydroethanolic & 22,00 & \pm & 1,000 & & 17,00 & \pm & 4,000 & \\
\hline $1: 8$ & Aqueous & 17,33 & \pm & 4,933 & \multirow{2}{*}{0,220} & 18,33 & \pm & 3,786 & \multirow{2}{*}{0,195} \\
\hline $65,5 \mathrm{mg} / \mathrm{mL}$ & Hydroethanolic & 21,67 & \pm & 1,528 & & 14,67 & \pm & 1,528 & \\
\hline $1: 16$ & Aqueous & 13,33 & \pm & 3,055 & \multirow{2}{*}{0,038} & 17,00 & \pm & 3,606 & \multirow{2}{*}{0,109} \\
\hline $31,25 \mathrm{mg} / \mathrm{mL}$ & Hydroethanolic & 19,33 & \pm & 1,528 & & 12,67 & \pm & 0,577 & \\
\hline $1: 32$ & Aqueous & 13,33 & \pm & 3,215 & \multirow{2}{*}{0,166} & 13,67 & \pm & 1,528 & \multirow{2}{*}{0,345} \\
\hline $16,65 \mathrm{mg} / \mathrm{mL}$ & Hydroethanolic & 16,67 & \pm & 1,155 & & 12,33 & \pm & 1,528 & \\
\hline $1: 64$ & Aqueous & 16,67 & \pm & 3,055 & \multirow{2}{*}{0,260} & 14,67 & \pm & 2,887 & \multirow{2}{*}{0,624} \\
\hline $7,81 \mathrm{mg} / \mathrm{mL}$ & Hydroethanolic & 13,67 & \pm & 2,517 & & 13,67 & \pm & 1,528 & \\
\hline $1: 128$ & Aqueous & 13,33 & \pm & 1,528 & \multirow{2}{*}{0,537} & 13,67 & \pm & 2,887 & \multirow{2}{*}{0,759} \\
\hline $3,9 \mathrm{mg} / \mathrm{mL}$ & Hydroethanolic & 15,00 & \pm & 4,000 & & 13,00 & \pm & 2,000 & \\
\hline $1: 256$ & Aqueous & 8,00 & \pm & 7,211 & \multirow{2}{*}{0,293} & 11,67 & \pm & 1,155 & \multirow{2}{*}{1,000} \\
\hline $1,95 \mathrm{mg} / \mathrm{mL}$ & Hydroethanolic & 13,33 & \pm & 2,517 & & 11,67 & \pm & 1,528 & \\
\hline $1: 512$ & Aqueous & 3,67 & \pm & 6,351 & \multirow{2}{*}{0,469} & 3,67 & \pm & 6,351 & \multirow{2}{*}{0,151} \\
\hline $0,97 \mathrm{mg} / \mathrm{mL}$ & Hydroethanolic & 8,00 & \pm & 6,928 & & 10,67 & \pm & 2,517 & \\
\hline
\end{tabular}

Table 1 shows that, when comparing both extracts, HE was superior to AE, but the control group showed better results when compared to extracts.

In comparing the inhibitory bacterial growth activity of S. mombin L. AE with that of the control group, it was verified that $\mathrm{AE}$ was statistically superior to $0.12 \%$ chlorhexidine digluconate solution $(\mathrm{p}<0.05)$ for Pseudomonas aeruginosa from its crude concentration $(500 \mathrm{mg} / \mathrm{ml})$ to the concentration of $125 \mathrm{mg} / \mathrm{ml}$ (1:4 dilution), and the concentration of $7.81 \mathrm{mg} / \mathrm{ml}$ (1:64 dilution) to the concentration $1.95 \mathrm{mg} / \mathrm{ml}$ (1:256 dilution). No statistically significant difference was observed between the test and control groups for Enterococcus faecalis (Table 2). 
Table 2. Statistical results obtained from the comparison between the inhibition halo means of the S. mombin L. aqueous extract and the $0.12 \%$ chlorhexidine digluconate solution in different concentrations against the Enterococcus faecalis and Pseudomonas aeruginosa microorganisms.

\begin{tabular}{|c|c|c|c|c|c|c|c|c|c|}
\hline & & \multicolumn{4}{|c|}{$\begin{array}{c}\text { Enterococcus faecalis } \\
\text { ATCC } 29212\end{array}$} & \multicolumn{4}{|c|}{$\begin{array}{c}\text { Pseudomonas aeruginosa } \\
\text { ATCC } 9027\end{array}$} \\
\hline & & Mean & & SD & $p$ & Mean & & $\mathrm{SD}$ & $p$ \\
\hline \multirow{2}{*}{$\begin{array}{c}1: 1 \\
500 \mathrm{mg} / \mathrm{mL}\end{array}$} & Aqueous & 27,00 & \pm & 4,359 & \multirow{2}{*}{0,167} & 27,00 & \pm & 1,732 & \multirow{2}{*}{0,006} \\
\hline & Chlorhexidine & 21,00 & \pm & 4,359 & & 15,67 & \pm & 3,215 & \\
\hline & Aqueous & 20,33 & \pm & 6,028 & \multirow{2}{*}{1,000} & 21,67 & \pm & 2,082 & \multirow{2}{*}{0,018} \\
\hline $250 \mathrm{mg} / \mathrm{mL}$ & Chlorhexidine & 20,33 & \pm & 3,512 & & 14,67 & \pm & 2,308 & \\
\hline & Aqueous & 19,00 & \pm & 4,583 & \multirow{2}{*}{0,742} & 19,33 & \pm & 2,517 & \multirow{2}{*}{0,023} \\
\hline $125 \mathrm{mg} / \mathrm{mL}$ & Chlorhexidine & 18,00 & \pm & 1,732 & & 13,00 & \pm & 1,732 & \\
\hline & Aqueous & 17,33 & \pm & 4,933 & \multirow{2}{*}{0,539} & 18,33 & \pm & 3,786 & \multirow{2}{*}{0,119} \\
\hline $65,5 \mathrm{mg} / \mathrm{mL}$ & Chlorhexidine & 15,33 & \pm & 1,528 & & 8,67 & \pm & 7,572 & \\
\hline $1: 16$ & Aqueous & 13,33 & \pm & 3,055 & \multirow{2}{*}{0,738} & 17,00 & \pm & 3,606 & \multirow{2}{*}{0,119} \\
\hline $31,25 \mathrm{mg} / \mathrm{mL}$ & Chlorhexidine & 14,00 & \pm & 1,000 & & 8,00 & \pm & 7,000 & \\
\hline $1: 32$ & Aqueous & 13,33 & \pm & 3,215 & \multirow{2}{*}{1,000} & 13,67 & \pm & 1,528 & \multirow{2}{*}{0,172} \\
\hline $16,65 \mathrm{mg} / \mathrm{mL}$ & Chlorhexidine & 13,33 & \pm & 2,082 & & 7,33 & \pm & 6,428 & \\
\hline $1: 64$ & Aqueous & 16,67 & \pm & 3,055 & \multirow{2}{*}{0,112} & 14,67 & \pm & 2,887 & \multirow{2}{*}{0,038} \\
\hline $7,81 \mathrm{mg} / \mathrm{mL}$ & Chlorhexidine & 12,33 & \pm & 2,082 & & 3,33 & \pm & 5,774 & \\
\hline $1: 128$ & Aqueous & 13,33 & \pm & 1,528 & \multirow[b]{2}{*}{0,382} & 13,67 & \pm & 2,887 & \multirow[b]{2}{*}{0,036} \\
\hline $3,9 \mathrm{mg} / \mathrm{mL}$ & Chlorhexidine & 11,67 & \pm & 2,517 & & 3,00 & \pm & 5,196 & \\
\hline $1: 256$ & Aqueous & 8,00 & \pm & 7,211 & \multirow{2}{*}{0,572} & 11,67 & \pm & 1,155 & \multirow{2}{*}{0,048} \\
\hline $1,95 \mathrm{mg} / \mathrm{mL}$ & Chlorhexidine & 10,67 & \pm & 2,082 & & 3,00 & \pm & 5,196 & \\
\hline $1: 512$ & Aqueous & 3,67 & \pm & 6,351 & \multirow{2}{*}{0,495} & 3,67 & \pm & 6,351 & \multirow{2}{*}{0,374} \\
\hline $0,97 \mathrm{mg} / \mathrm{mL}$ & Chlorhexidine & 0,00 & \pm & 0,000 & & 0,00 & \pm & 0,000 & \\
\hline
\end{tabular}

Table 2 shows that the AE was superior to the control group in certain concentrations for Pseudomonas aeruginosa, however this was not observed for Enterococcus faecalis.

When comparing the inhibitory bacterial growth activities between the control group and the S. mombin L. HE, it was observed that the extract was statistically superior to chlorhexidine $(\mathrm{p}<0.05)$ for Pseudomonas aeruginosa in its crude concentration $(500 \mathrm{mg} / \mathrm{ml})$ and in its most diluted form $(0.97 \mathrm{mg} / \mathrm{ml})$, as well as in the concentrations $7.81 \mathrm{mg} / \mathrm{ml}(1: 64$ dilution) and $3.90 \mathrm{mg} / \mathrm{ml}$ (1:128 dilution). For Enterococcus faecalis, the HE was statistically superior to chlorhexidine $(\mathrm{p}<0.05)$ in its crude concentration $(500 \mathrm{mg} / \mathrm{ml})$ and the concentration of $125 \mathrm{mg} / \mathrm{ml}$ (1:4 dilution) up to the concentration $31.25 \mathrm{mg} / \mathrm{ml}$ (1:16 dilution) (Table 3). 
Table 3. Statistical results obtained from the comparison between the inhibition halo means of the S. mombin L. hydroethanolic extract and the $0.12 \%$ chlorhexidine digluconate solution in different concentrations against the Enterococcus faecalis and Pseudomonas aeruginosa microorganisms.

\begin{tabular}{|c|c|c|c|c|c|c|c|c|c|}
\hline & & \multicolumn{4}{|c|}{$\begin{array}{c}\text { Enterococcus faecalis } \\
\text { ATCC } 29212\end{array}$} & \multicolumn{4}{|c|}{$\begin{array}{c}\text { Pseudomonas aeruginosa } \\
\text { ATCC } 9027\end{array}$} \\
\hline \multirow{3}{*}{$\begin{array}{c}1: 1 \\
500 \mathrm{mg} / \mathrm{mL}\end{array}$} & & Mean & & $\mathrm{SD}$ & $p$ & Mean & & $\mathrm{SD}$ & $p$ \\
\hline & Hydroethanolic & 27,00 & \pm & 4,359 & \multirow{2}{*}{0,029} & 28,00 & \pm & 2,646 & \multirow{2}{*}{0,007} \\
\hline & Chlorhexidine & 30,67 & \pm & 2,517 & & 15,67 & \pm & 3,215 & \\
\hline \multirow{2}{*}{$\begin{array}{c}1: 2 \\
250 \mathrm{mg} / \mathrm{mL}\end{array}$} & Hydroethanolic & 20,33 & \pm & 6,028 & \multirow{2}{*}{0,092} & 18,67 & \pm & 2,082 & \multirow{2}{*}{0,090} \\
\hline & Chlorhexidine & 26,67 & \pm & 3,512 & & 14,67 & \pm & 2,308 & \\
\hline \multirow{2}{*}{$\begin{array}{c}1: 4 \\
125 \mathrm{mg} / \mathrm{mL}\end{array}$} & Hydroethanolic & 22,00 & \pm & 1,000 & \multirow{2}{*}{0,026} & 17,00 & \pm & 4,000 & \multirow{2}{*}{0,187} \\
\hline & Chlorhexidine & 18,00 & \pm & 1,732 & & 13,00 & \pm & 1,732 & \\
\hline \multirow{2}{*}{$\begin{array}{c}1: 8 \\
65,5 \mathrm{mg} / \mathrm{mL}\end{array}$} & Hydroethanolic & 21,67 & \pm & 1,528 & \multirow{2}{*}{0,007} & 14,67 & \pm & 1,528 & \multirow{2}{*}{0,250} \\
\hline & Chlorhexidine & 15,33 & \pm & 1,528 & & 8,67 & \pm & 7,572 & \\
\hline \multirow{2}{*}{$\begin{array}{c}1: 16 \\
31,25 \mathrm{mg} / \mathrm{mL}\end{array}$} & Hydroethanolic & 19,33 & \pm & 1,528 & \multirow{2}{*}{0,007} & 12,67 & \pm & 0,577 & \multirow{2}{*}{0,314} \\
\hline & Chlorhexidine & 14,00 & \pm & 1,000 & & 8,00 & \pm & 7,000 & \\
\hline \multirow{2}{*}{$\begin{array}{c}1: 32 \\
16,65 \mathrm{mg} / \mathrm{mL}\end{array}$} & Hydroethanolic & 16,67 & \pm & 1,155 & \multirow{2}{*}{0,072} & 12,33 & \pm & 1,528 & \multirow{2}{*}{0,260} \\
\hline & Chlorhexidine & 13,67 & \pm & 2,082 & & 7,33 & \pm & 6,428 & \\
\hline \multirow{2}{*}{$\begin{array}{c}1: 64 \\
7,81 \mathrm{mg} / \mathrm{mL}\end{array}$} & Hydroethanolic & 13,67 & \pm & 2,517 & \multirow{2}{*}{0,519} & 12,67 & \pm & 1,528 & \multirow{2}{*}{0,040} \\
\hline & Chlorhexidine & 12,33 & \pm & 2,082 & & 3,33 & \pm & 5,774 & \\
\hline \multirow{2}{*}{$\begin{array}{c}1: 128 \\
3,9 \mathrm{mg} / \mathrm{mL}\end{array}$} & Hydroethanolic & 15,00 & \pm & 4,000 & \multirow{2}{*}{0,289} & 13,0 & \pm & 2,000 & \multirow{2}{*}{0,036} \\
\hline & Chlorhexidine & 11,67 & \pm & 2,517 & & 3,00 & \pm & 5,196 & \\
\hline \multirow{2}{*}{$\begin{array}{c}1: 256 \\
1,95 \mathrm{mg} / \mathrm{mL}\end{array}$} & Hydroethanolic & 13,33 & \pm & 2,517 & \multirow[b]{2}{*}{0,230} & 11,67 & \pm & 1,528 & \multirow[b]{2}{*}{0,050} \\
\hline & Chlorhexidine & 10,67 & \pm & 2,082 & & 3,00 & \pm & 5,196 & \\
\hline $1: 512$ & Hydroethanolic & 8,00 & \pm & 6,928 & \multirow{2}{*}{0,219} & 10,67 & \pm & 2,517 & \multirow{2}{*}{0,002} \\
\hline $0,97 \mathrm{mg} / \mathrm{mL}$ & Chlorhexidine & 0,00 & \pm & 0,000 & & 0,00 & \pm & 0,000 & \\
\hline
\end{tabular}

Source: Authors.

Table 3 shows that HE was superior to the control group in some concentrations, both for Pseudomonas aeruginosa and Enterococcus faecalis.

\subsection{Minimum Inhibitory Adherence Concentration (MIAC) analysis}

S. mombin L. AE presented anti-adherent effect on Pseudomonas aeruginosa at all tested concentrations, and up to a concentration of $0.97 \mathrm{mg} / \mathrm{ml}$ (1:512 dilution) for Enterococcus faecalis. On the other hand, S. mombin L. HE presented antiadherent effect on the two tested bacteria until the $1: 512$ dilution $(0.97 \mathrm{mg} / \mathrm{mL})$. The $0.12 \%$ chlorhexidine digluconate prevented Pseudomonas aeruginosa adhesion to the glass tube walls until the concentration of 1.95 $\mathrm{mg} / \mathrm{ml}$ (1:256 dilution), and of Enterococcus faecalis to the concentration $0.97 \mathrm{mg} / \mathrm{ml}$ (1:512 dilution).

\subsection{Bactericidal Kinetics (BK) analysis}

In its crude form, S. mombin L. AE exhibited a bactericidal effect on Pseudomonas aeruginosa in the first two hours of contact with the bacterium, and at its Minimum Inhibitory Concentration (MIC) in the first four hours of contact. Regarding Enterococcus faecalis, both the crude aqueous extract and the aqueous extract diluted to its MIC showed bactericidal activity 
in the first four hours of contact. Crude S. mombin L. HE demonstrated a bactericidal effect on the two tested microorganisms in the first two hours of contact, and at their MIC in the first four hours of contact with Enterococcus faecalis and in the first two contact hours with Pseudomonas aeruginosa. The control group showed bactericidal effect for the two investigated microorganisms at both its crude concentration and at its MIC in the first two hours of contact with the two bacteria.

\section{Discussion}

In order to reduce bacterial resistance and the costs and side effects that are usually observed in conventional synthetic antimicrobial agents and considering the great ethnobotanical variety, the antimicrobial action of plant extracts against microorganisms commonly found in the buccal environment and against superinfecting pathogens has been studied. In addition, with the association of ethnopharmacology to chemical studies, many experiments have investigated these extracts through their phytochemical characterization and pharmacological application (Medeiros et al., 2013). In this sense, the present study proposed to perform phytochemical screening of a very common plant extract in Latin American countries, and to compare its antimicrobial activity against two microorganisms in the oral cavity which are difficult to eradicate, namely Pseudomonas aeruginosa and Enterococcus faecalis, with the antimicrobial activity of $0.12 \%$ chlorhexidine digluconate solution which is considered the gold standard in dentistry.

In the present study, both $S$. mombin L. extracts showed superior antimicrobial activity in different concentrations (inhibitory bacterial growth capacity, anti-adherence effect and bactericidal potential) to $0.12 \%$ chlorhexidine digluconate against Pseudomonas aeruginosa and/or Enterococcus faecalis, rejecting the null hypothesis of this experiment. With regard to the chemical characterization of the extracts, the results of this research revealed the presence of phenolic compounds, flavonoids, tannins and saponins through a previous phytochemical prospection followed by a TLC analysis; which is in agreement with what was found in the study by Medeiros et al. (2013) (Medeiros et al., 2013). Since several experiments (Corthout et al., 1992; Elzaawely et al., 2005; Kannan et al., 2011) have demonstrated the effectiveness of phenolic compounds, flavonoids and tannins as antimicrobial agents and antioxidants, it is possible that the great antibacterial activity presented by the two extracts tested in the present study is attributed to the presence of these metabolites in composition.

Some studies (Delazar et al., 2006; Thadhani et al., 2012) have demonstrated that phenolic compounds present antioxidant, antiviral, antibiotic, antitumor and allergenic actions. Phenolic-core substances, such as flavonoids, also stand out as antioxidants (Delazar et al., 2006), while tannins are notable for their antimicrobial activity (Gülçin et al., 2010). In addition, Yao et al. (2014) found that some saponins also have anti-inflammatory action (Yao et al., 2014), which could justify a subsequent investigation of the S. mombin L. extract as a possible anti-inflammatory agent. In this study, the inhibitory bacterial growth action of S. mombin L. extracts and $0.12 \%$ chlorhexidine digluconate on Enterococcus faecalis and Pseudomonas aeruginosa was evaluated by MIC, which is considered the most appropriate method for this purpose (Natarajan et al., 2005), since MIC is especially used to confirm the resistance of microorganisms to an antimicrobial agent, and also to monitor the activity of new antimicrobial agents; this was the main reason for its application in the present study. The results revealed that $S$. mombin $L$. HE exhibited superior inhibitory bacterial growth activity at different concentrations to $0.12 \%$ chlorhexidine digluconate against the two investigated microorganisms, whereas the aqueous extract, also in different concentrations, was only superior to the $0.12 \%$ chlorhexidine digluconate against Pseudomonas aeruginosa.

Despite the fact that both $S$. mombin $L$. extracts at certain concentrations demonstrated a superior inhibitory bacterial growth effect than the $0.12 \%$ chlorhexidine digluconate against one or two of the studied microorganisms, no difference was observed between these extracts for the referred effect against Pseudomonas aeruginosa. However, for Enterococcus faecalis, $\mathrm{HE}$ at a given concentration exhibited higher inhibitory growth activity than AE. In addition, HE presented inhibitory bacterial growth activity for both investigated bacteria at lower concentrations than $\mathrm{AE}$, and was also the substance that produced the 
highest inhibition halos at the lowest tested concentration. This higher antimicrobial activity of HE when compared to AE may be associated with a higher extraction of antimicrobial chemical compounds (secondary metabolites) by ethanol than by water. Nevertheless, it would be necessary to carry out quantification tests by High Performance Liquid Chromatography (HPLC) in order to confirm this hypothesis, as recommended by Wu et al. (2015) (Wu et al., 2015).

In addition to investigating the inhibitory bacterial growth effect of S. mombin $L$. extracts, the effect of these extracts on bacterial adherence (non-stick effect) was also verified in the present study, since the adherence of bacteria to the acquired enamel film represents one of the first mechanisms involved in the dental biofilm formation process (Jongsma et al., 2015). In order to investigate the Minimum Inhibitory Intake Concentration (MIAC) of the S. mombin L. extracts against the Enterococcus faecalis and Pseudomonas aeruginosa microorganisms, extracts at different concentrations prevented the bacteria adherence to the glass tube walls (simulating a smooth dental surface). This non-adherent effect for both AE and HE was higher than that of the $0.12 \%$ chlorhexidine digluconate for Pseudomonas aeruginosa, and similar to the latter for Enterococcus faecalis. These results strongly suggest that $S$. mombin $L$. extracts can be successfully used to chemically control dental biofilm. However, studies on the activity of these extracts on bacteria organized in biofilm are necessary to validate its anti-biofilm effect.

The lower chlorhexidine digluconate activity against Pseudomonas aeruginosa when compared to the activity of both S. mombin L. extracts can be attributed to the low concentration of $0.12 \%$ used in this study. However, considering the presence of such bacteria in the buccal environment, no different concentration could have been used since this is the reputed accepted concentration in the buccal mucosa. However, since Pseudomonas aeruginosa is commonly associated with hospital infections (Peña, et al., 2013; Lucena et al., 2014) and the chlorhexidine concentration used at the hospital level is much higher, ranging from $2 \%$ to $5 \%$ (Shukla et al., 2016), it is necessary to perform new laboratory tests using higher chlorhexidine concentrations in order to compare its actual antibacterial activity against Pseudomonas aeruginosa with that promoted by these extracts.

Regarding the bactericidal effect of the investigated extracts, the results of this research revealed that both $\mathrm{AE}$ and $\mathrm{HE}$ in their crude and diluted concentrations (MIC) exhibited bactericidal action within the first two to four hours of initial contact with Enterococcus faecalis and Pseudomonas aeruginosa, although this latter bacterium was more sensitive to the two extracts than the first. Also, and the crude extracts showed faster action than those diluted to their MICs, especially the crude hydroethanolic extract which, similar to $0.12 \%$ chlorhexidine digluconate, exerted a bactericidal effect on the two bacteria within the first two hours of contact with them, suggesting its clinical indication for eliminating superinfecting bacteria such as Enterococcus faecalis and Pseudomonas aeruginosa commonly present in the oral environment, either inside the root canal and/or periodontal pockets, as well as for dental prostheses (O'donnell et al., 2016). However, for its clinical application as an oral antiseptic or irrigating substance, it is still necessary to investigate the effect of this extract on dental structure, restorative materials and oral mucosa cells. In this context, Cabral et al. (2016) already verified that S. mombin L. HE, in low concentrations, did not exert a cytotoxic effect on the fibroblasts (Cabral et al., 2016).

In comparing the antimicrobial action of $S$. mombin $L$. extracts and the antimicrobial action of $0.12 \%$ chlorhexidine digluconate, it is important to emphasize that the latter has a duration of approximately 12 hours, having an initial bactericidal action immediately after being used as mouthwash, combined with a prolonged bacteriostatic action since it is strongly adsorbed by the oral surfaces, forming "chlorhexidine reservoirs" which are released gradually (Quintas et al., 2015). In this sense, aiming at a later clinical application, the need to also investigate the duration of S. mombin L. extracts also seems obvious. 
As limitations of this study, we can include the exclusive use of commercial strains and only investigating these strains in their planktonic form, thus indicating the need for additional studies that also evaluate microorganisms from clinical isolates and investigate these microorganisms in mixed and organized culture in biofilms.

\section{Conclusion}

The $S$. mombin $L$. aqueous and hydroethanolic extracts demonstrated a superior antimicrobial activity in different concentrations to $0.12 \%$ chlorhexidine digluconate against Pseudomonas aeruginosa and/or Enterococcus faecalis, with this activity being associated to the chemical characterization of the extracts, which exhibited phenolic derivatives, flavonoids, tannins and saponins in their composition.

Additional studies should be carried out to evaluate the activities of the aqueous and hydroethanolic extracts of Spondias mombin L. against clinical isolates of microorganisms and on microorganisms in mixed cultures and organized in biofilms.

\section{References}

Abo, K. A., Ogunleye, V. O., \& Ashidi, J. S. (1999). Antimicrobial potential of Spondias mombin, Croton zambesicus and Zygotritonia crocea. Phytotherapy Research: An International Journal Devoted to Pharmacological and Toxicological Evaluation of Natural Product Derivatives, $13(6), 494-497$.

Adedokun, M. O., Oladoye, A. O., Oluwalana, S. A., \& Mendie, I. I. (2010). Socio-economic importance and utilization of Spondias mombin in Nigeria. Asian Pacific Journal of Tropical Medicine, 3(3), 232-234.

Allaker, R. P., \& Douglas, C. I. (2009). Novel anti-microbial therapies for dental plaque-related diseases. International journal of antimicrobial agents, 33(1), $8-13$.

Bayer, A. W., Kirby, W. M. M., Sherris, J. C., \& Turck, M. (1966). Antibiotic susceptibility testing by a standardized single disc method. American journal of clinical pathology, 45(4), 493-496.

Beganovic, M, Luther, M. K, Rice, L. B, Arias, C. A, Rybak, M. J, LaPlante, K. L. (2018). A Review of Combination Antimicrobial Therapy for Enterococcus Faecalis Bloodstream Infections and Infective Endocarditis. Clinical Infectious Diseases, 67(2), 303-309.

Cabral, B, Siqueira, E, Bitencourt, M. A, Lima, M. C, Lima, A. K, Ortmann, C. F, et al. (2016). Phytochemical study and anti-inflammatory and antioxidant potential of Spondias mombin leaves. Revista Brasileira de Farmacognosia, 26(3), 304-311.

Caldas, R. R, Le Gall, F., Revert, K., Rault, G., Virmaux, M., Gouriou, S., et al. (2015). Pseudomonas aeruginosa and periodontal pathogens in the oral cavity and lungs of cystic fibrosis patients: a case-control study. Journal of clinical microbiology, 53(6), 1898-1907.

Chakraborty, A, Brantner AH (1999). Antibacterial steroid alkaloids from the stem bark of Holarrhena pubescens. Journal of Ethnopharmacology, 68(1-3): 339-344.

Colombo, A. V, Barbosa, G. M., Higashi, D., Di Micheli, G., Rodrigues, P. H., Simionato, M. R. L. (2013). Quantitative detection of Staphylococcus aureus, Enterococcus faecalis and Pseudomonas aeruginosa in human oral epithelial cells from subjects with periodontitis and periodontal health. Journal of medical microbiology, 62(10), 1592-1600.

Corthout, J., Pieters, L., Claeys, M., Berghe, D. V., Vlietinck, A (1992). Antiviral caffeoyl esters from Spondias mombin. Phytochemistry, 31(6): 1979-1981.

Delazar, A., Talischi, B., Nazemiyeh, H., Rezazadeh, H., Nahar, L., Sarker, S. D. (2006). Chrozophorin: a new acylated flavone glucoside from Chrozophora tinctoria (Euphorbiaceae). Revista Brasileira de Farmacognosia, 16(3), 286-290.

Elzaawely, A. A., Xuan, T. D., Tawata, S. (2005). Antioxidant and antibacterial activities of Rumex japonicus HOUTT. Aerial parts. Biological and Pharmaceutical Bulletin, 28(12), 2225-2230.

Gomes, M. S., Lins, R. D. A. U., Langassner, S. M. Z., Silveira, É. J. D., Carvalho, T. G., Lopes, M. L. D., et al. (2020). Anti-inflammatory and antioxidant activity of hydroethanolic extract of Spondias mombin leaf in an oral mucositis experimental model. Archives of Oral Biology, p. $104664,2020$.

Gülçin, İ., Huyut, Z., Elmastaş, M., Aboul-Enein, H. Y. (2010). Radical scavenging and antioxidant activity of tannic acid. Arabian Journal of Chemistry, 3(1), 43-53.

Jongsma, M. A., Van de Lagemaat, M., Busscher, H. J., Geertsema-Doornbusch, G. I., Atema-Smit, J., Van Der Mei, H. C., et al. (2015). Synergy of brushing mode and antibacterial use on in vivo biofilm formation. Journal of dentistry, 43(12), 1580-1586.

Kadan, S., Saad, B., Sasson, Y., Zaid, H. (2016). In vitro evaluation of anti-diabetic activity and cytotoxicity of chemically analysed Ocimum basilicum extracts. Food chemistry, 196, 1066-1074.

Kannan, S., Devi, B. P., Jayakar, B. (2011). Antibacterial activity of Passiflora ligularis. International Journal of Chemical Sciences, 9(1), 393-396. 
Lucena, A., Dalla Costa, L. M., Nogueira, K. S., Matos, A. P., Gales, A. C., Paganini, M. C., et al. (2014). Nosocomial infections with metallo-beta-lactamaseproducing Pseudomonas aeruginosa: molecular epidemiology, risk factors, clinical features and outcomes. Journal of Hospital Infection, 87(4), 234-240.

Lysakowska, M. E., Ciebiada-Adamiec, A., Sienkiewicz, M., Sokołowski, J., Banaszek, K. (2016). The cultivable microbiota of primary and secondary infected root canals, their susceptibility to antibiotics and association with the signs and symptoms of infection. International endodontic journal, 49(5), 422430 .

Medeiros, P. M., Ladio, A. H., Santos, A. M. M., Albuquerque, U. P. (2013). Does the selection of medicinal plants by Brazilian local populations suffer taxonomic influence? Journal of ethnopharmacology, 146(3), 842-852.

Natarajan, D, Britto, S. J., Srinivasan, K., Nagamurugan, N., Mohanasundari, C., Perumal, G. (2005). Anti-bacterial activity of Euphorbia fusiformis-A rare medicinal herb. Journal of ethnopharmacology, 102(1), 123-126.

Nworu, C. S., Akah, P. A., Okoye, F. B., Toukam, D. K., Udeh, J., Esimone, C. O. (2011). The leaf extract of Spondias mombin L. displays an antiinflammatory effect and suppresses inducible formation of tumor necrosis factor- $\alpha$ and nitric oxide (NO). Journal of immunotoxicology, 8(1), 10-16.

O'Donnell, L. E., Smith, K., Williams, C., Nile, C. J., Lappin, D. F., Bradshaw, D., et al. (2016). Dentures are a reservoir for respiratory pathogens. Journal of Prosthodontics, 25(2), 99-104

O’Driscoll, T., Crank, C. W. (2015). Vancomycin-resistant enterococcal infections: epidemiology, clinical manifestations, and optimal management. Infection and drug resistance, $8,217$.

Peña, C., Suarez, C., Ocampo-Sosa, A., Murillas, J., Almirante, B., Pomar, V., et al. (2013). Effect of adequate single-drug vs combination antimicrobial therapy on mortality in Pseudomonas aeruginosa bloodstream infections: a post hoc analysis of a prospective cohort. Clinical infectious diseases, 57(2), 208216.

Pereira, A. S., Shitsuka, D. M., Parreira, F. J., \& Shitsuka, R. (2018). Metodologia da pesquisa científica.

Peyret, M., Carret, G., Carre, C., Fardel, G., Flandrois, J. P. (1990). Mathematical study of the sensitivity curves of Escherichia coli exposed to polymyxins. Pathologie-biologie, 38(5), 441-445.

Quintas, V., Prada-Lopez, I., Donos, N., Suarez-Quintanilla, D., Tomas, I (2015). In situ neutralisation of the antibacterial effect of 0.2\% Chlorhexidine on salivary microbiota: Quantification of substantivity. Archives of oral biology, 60(8), 1109-1116.

Rams, T. E., Degener, J. E., Winkelhoff, A. V. (2013). Prevalence of $\beta$-lactamase-producing bacteria in human periodontitis. Journal of Periodontal Research, 48(4): 493-499.

Shukla, N., Saha, S., Singh, S. (2016). Effect of Chlorhexidine with Fluoride Mouthrinse on Plaque Accumulation, Plaque pH-A Double Blind Parallel Randomized Clinical Trial. Journal of clinical and diagnostic research: JCDR, 10(7), ZC62.

Smania Jr, A., Monache, F. D., Smania, E. D. F. A., Cuneo, R. S. (1999). Antibacterial activity of steroidal compounds isolated from Ganoderma applanatum (Pers.) Pat.(Aphyllophoromycetideae) fruit body. International Journal of medicinal mushrooms, 1(4).

Souto, R., Silva-Boghossian, C. M., Colombo, A. P. V. (2014). Prevalence of Pseudomonas aeruginosa and Acinetobacter spp. in subgingival biofilm and saliva of subjects with chronic periodontal infection. Brazilian Journal of Microbiology, 45(2), 495-501.

Thadhani, V. M., Choudhary, M. I., Khan, S., Karunaratne., V. (2012). Antimicrobial and toxicological activities of some depsides and depsidones. Journal of the National Science Foundation of Sri Lanka, 40(1), 43-48.

Wei, J., Jingping, L. (2015). Transcriptome analysis of Enterococcus faecalis in response to alkaline stress. Frontiers in microbiology, 6, 795.

Wu, X., Cao, G., Li, Q., Cai, B., Hu, S. (2015). Quantitative evaluation main of the components in Paeoniae Radix Alba-Atractylodis Macrocephalae Rhizoma herbal pair by high-performance liquid chromatography. Journal of separation science, 38(2), 239-246.

Yao, Y., Yang, X., Shi, Z., Ren, G. (2014). Anti-Inflammatory Activity of Saponins from Quinoa (Chenopodium quinoa Willd.) Seeds in Lipopolysaccharide-Stimulated RAW 264.7 Macrophages Cells. Journal of food science, 79(5).

Zoletti, G. O., Pereira, E. M., Schuenck, R. P., Teixeira, L. M., Siqueira, J. F., Santos, K. R. N. (2011). Characterization of virulence factors and clonal diversity of Enterococcus faecalis isolates from treated dental root canals. Research in Microbiology, 162(2): 151-158. 